\title{
Gendered Subaltern in Abhi Subedi's Dreams of Peach Blossoms ${ }^{1}$
}

\section{Sanjeev Niraula}

\begin{abstract}
This paper examines the consciousness of gendered subaltern in Abhi Subedi's poetic play Dreams of Peach Blossoms and looks at how Subedi deconstructs the existing historiography to bring forth the issue of gendered subaltern who have been subjected to the hegemony of the ruling class. Drawing on insights and postulations from Subaltern Studies theorists such as Gayatri Chakravorty Spivak, Partha Chatterjee, Gautam Bhadra and others, this paper examines the pain and agonies of female characters that are glossed over in the grand narrative of the mainstream culture. This paper concludes that while exploring the painful experience of women erased from the pages of history, Subedi is focused on the Maiju culture that began since Bhrikuti's marriage to a Tibetan King in the sixth century and reveals the injustice of patriarchy against women with an aim to make correction in such distortions of history.
\end{abstract}

Keywords: Gendered subaltern, Elite historiography, Hegemony, Representation, Subaltern consciousness

Abhi Subedi's poetic play Dreams of Peach Blossoms (2001) is entangled in the painful tradition of Maijus. Set in Bhaktapur, this play moves around the stories of women speaking of their agonies and pain. Subedi in the play, represents a young woman Maiju, the cultural descendant of Bhrikuti as the central character who is about to get married and sent off like the historical character Bhrikuti and who appears to be resisting her marriage that would take her away from her beloved homeland. In fact, she is an archetype of all the young women who were thus married off. As Subedi asserts in the preface of this play that

\footnotetext{
${ }^{1}$ Cite this article as: Niraula, S. (2021). Contemporary Research: An Interdisciplinary Academic Journal, vol. 5 (1) DOI: https://doi.org/10.3126/craiaj.v5i1.40490

Sanjeev Niraula, Lecturer, Kathmandu Model College, Kathmandu, Nepal

Email: sanjeev.niraula42@gmail.com

Article history: Received on August 31; Accepted on September 17; Published on October 21

Peer reviewed under the authority of CRAIAJ, academic journal of Ghodaghodi Multiple Campus, Kailali, Nepal, with ISSN 2717-4611 (Print) and ISSN 2717-462X (Online).

(C) 2021 CRAIAJ
}

Full text of this article can be downloaded from www.craiaj.com and www.nepjol.info 
this poetic play is a lyrical meditation on the "treatment of women by strong men and the march of time through the millennia in this city (Bhaktapur) of ancient civilization and arts" (p. 45), this play revisits the history, explores and brings focus aspects of human history which have gone down in the pages of history as silent moments in the human relationship with the time.

Subedi has attempted to explore the silent-spots of Nepalese history in which Bhrikuti's marriage to Tibetan Emperor has set down the painful tradition following which Many Bhrikuti's sisters are married to an alien land with alien language, customs. traditions and never to home. However, as such silent spots are presented as glorious and pleasant moments, and the tension and agonies involved in such tropes of history are glossed over in the grand narrative, Subedi fuses history and poetry to capture those silent spots of history. To capture such silent spots, he views poetry as the appropriate medium he writes in the preface, "poetry is only medium to capture such moments, such silent spots in history" (p. 46).

The play hinges on the substantiation through implication and enactment of events, of what a female character says to the Poet: "you have written our history" (p. 74). And this is the history where women are invisible and their voices suppressed. A realization that hitherto written history is the history of man written with the power of the sword is itself a critique of subordination and marginalization of women. An implicit in this critique is an appeal to write women's history where women's stories are not carved out the way it is and where women's dreams, instead of withering away like peach blossoms, shatter the walls around them.

Abhi Subedi has published over a dozen books on literature and cultural studies in Nepali and English. Some of his seminal works include Dreams of Mayadevi, Dreams of Peach Blossoms, Fire in the Monastery etc. Fire in the Monastery is a set in a certain monastery of the Tibetan Buddhist order in the mountain of Nepal. It is a play about the concept, quest, queries and quirks that the characters show during the course of the action. Human beings are caught between rigidity and movement. Characters disturbed by their information about the fire that consumes an old library somewhere in the precincts of the monastery, try to read more meaning in the simple event than it is necessary. The fire only works as a catalyst that brings different modes imagination together. The over interpretation or the misreading of the letters consumed by the fire, the letters the monks 
and the nuns have not seen or read, comes like a stone in the calm lake casting ripples. The play brings together the sense of insecurity caused by fires and the uncertainties that pervade the minds of the acolytes, nuns and poet living under different conditions in different monasteries, and meeting only occasionally.

Similarly, Dreams of Mayadevi blends dream with reality. Principally, it dramatizes the predicament of women in the conflict affected areas. The mother's visit to the battlefield and her direct encounter of the gruesome scene, her encounter of the wounded youths all of the same age as her son Kale who has disappeared, makes a blend of the raw human suffering and love, affection and pain. The humble life of Mayadevi and the old man who has lost his hand in the bigger war of the region, and the difficulties faced by women due to the war are brought under sharp focus in the play.

Subedi in this poetic play Dreams of Peach Blossoms attempts to narrate the ancient stories in the modern time. The play also tells a story of Nepali princess Bhrikuti who was married to the Tibetan King in the 6th century. After the first theatrical presentation of this play under the direction of Shiva Rijal which saw its first production on the 9th November 2000 at Babar Mahal Revisited, it received claying coverage in the press. It was the dream of Sunil Pokharel, a prominent theater director, for doing this play in Nepali language for which the playwright himself translated this play into Nepali language under the title Aaruka Phulka Sapana and its theatrical presentation brought this play a tremendous popularity. Many critics came up with their own mind-frame works and the play was interpreted and analyzed from different perspectives.

D. P. Bhandari, a prominent literary figure, views this play as a table holding a drama and poetry together. In The Kantipur Daily, he regards this play as "a poetic conference of many items-a poetic conference holding a drama". It is the fusion of poetry and drama in the play that leads Bhandari to regard this play as a poetic conference. Similarly, Sangita Rayamajhi is touched by women's issue of the play. In Across magazine, she appreciates the play for the depiction of women's untold story behind the facade of heritage in moving words of dramatic and poetic subtlety." Bhuvan Dhungana in the Kantipur Daily, evaluates this play as the play speaking of the culture and tradition of Newari Community. Expressing his wishes for the play, he wants it "to bloom even in other languages apart from English and Nepali." Pravaw Basistha evaluates this play in terms of its form. He is basically concerned with the poetic devices of the play. Basistha in The 
Deshantar Weekly writes, "As a theatrical experiment in symbols, images and 'strokes', Dreams of Peach Blossoms as a poetic play, is an excellent experiment in Nepalese theatre."

Similarly, Carol Davis who holds a doctorate from the University of California, and teaches theatre at Pamona College, views this play as the play of cultural memory. Commenting on Dreams of Peach Blossoms, she asserts:

Dreams ofPeach Blossoms takes place in the mind of a poet who travels across time to his ancient cultural heritages before its ideas and icons are lost forever. Playwright Abhi Subedi juxtaposes indigenous elements with foreign influences and mixes historical values with contemporary exploitation as he exhorts his audience to preserve what is precious in their culture. (p. 79)

The crux of all these literature reviews, when brought together, hints at the various responses that the play was able to receive and at the same time, at various perspective through which the play was received ranging from the cultural memory to an experiment on the postmodern poetry. However, no one seems to be primarily interested in the silent spots of history, in the pain and agonies that was glossed over in the grand narrative, in the marginalization and subordination of women and in unfolding the so called 'glorious' and 'pleasant' history to perceive what actually lies behind them. After all, why does the playwright excavate the traces of memory erased from the pages of history?

Therefore, there exists a strong need to carry out research on this play from this new perspective. Without a study on the issue of the representation of the gendered subaltern in the text, the meaning of the text will remain incomplete. Having taken this fact into consideration, this paper seeks to carry out the research from the perspective of Subaltern Studies.

Maiju in the play, has to get married to an alien land, culture and tradition but considering it as the wish of her parents and her duty, she goes away never to return. Before her departure, her mind is occupied by momentous questions that she asks to no one. As David Glover and Kaplan Cora (2009) argue, woman gets described as the unfeminine when she exposes the "supposed coldness, aggression, ambition, neglect of children or high intelligence" (p. 3). She is not supposed to show the rationality and high-intelligence. Even 
if she possesses these qualities, she must avoid them and render her domestic duties in silence. In this regard, the stereotypical image of patriarchy has subdued the agency of the woman and lowered her to the status of subaltern. Once the patriarchy constructs the stereotypes, it imposes them on the woman as if the images are naturally given. In case, she tries to resist the stereotypical images, she becomes social outcast. Regardless of its impact on the personality development, one must try to adhere what Elisa Davila (2008) calls "a set of rules that dictate the manner by which she can act, talk, have sex and even think. A woman is supposed to accept domesticity and motherhood as the two guiding forces of her life" (p. 61). To act in accordance with the patriarchal principles is to be civilized. Else she turns out to be unfeminine and invites a chain of accusations upon herself.

Subedi, in his play, marks a break in the existing historiography by bringing forth the issue of gendered subalterns who have been subjected the hegemony of the ruling class. In the play, by revisiting the history, he unfolds the distortions and omissions regarding women's reality and their invisibility in the historiography that is based on the masculine standards, norms and values. Women are invisible in the elite historiography as their subjectivity, agency and individuality are never taken into consideration. Subedi in this play is concerned with this very problem of invisibility of women and thus is aimed at making women visible by exposing the silent spots of history. From the perspective of the subalterns he brings the stories of subaltern. Through the characters like the Guard and Poet he exposes the agonies and pain of Maiju and other women.

History treats women paradoxically both as invisible and culpable for unpleasant events in historical time. In the words of Maiju, who identifies herself with river Bagmati, "A woman is such a martyr/ Whose story is not written/ Only her broken evenings sing her saga/ Over the river that is trapped/ In its universal story" (p. 73). This play explores the fact that the hitherto written history is the history of men written by swords where women's dreams are never permitted to blossom; where women are forced to a subordinated and marginalized position and where women's realities are omitted and distorted in such a way so that it meets the taste of patriarchy. Maiju evaluates the history as the history of male and as the grave of women in her response to the Poet: "Your history is the grave of woman/Where you write the epitaph-/ One inside this was always invisible.” (p. 73) 
Maiju and other women as subalterns expose their contradictory consciousness in the play. Gramsci points out two different states of subaltern consciousness. In this context, he asserts:

The social group in question (subaltern group of great mass) may indeed have its own conception of the world, even if only embryonic; conception which manifests itself in action; but occasionally and in when, that is the group is acting as an organic totality. But the same group has reasons of submissions and intellectual subordination adopted a conception of another group. (qtd. In Chatterjee's Caste and Subaltern Consciousness, p. 170)

Gramsci points out that subaltern do have both autonomous and borrowed consciousness, in which the latter gets inculcated in them by the ruling classes. In such instances, the subalterns remain submissive and subordinate. In the play, after the palace banishes the Artist, his beloved in grief seeks suggestion from Maiju who speaks "In voice mixed with anger and confidence". She consoles the girl stating that they will seek the answer to this injustice in future and one day the girl will have reunion with her lover. Why does Maiju think of getting the answer in future? Why not in present? The long speech of consolation of Maiju exhibits subalterns' mentality of submissiveness. At the same time her voice mixed with anger and confidence suggests the sense of revolution mixed with submission to authority. Adding to this nature of subaltern consciousness, Chatterjee calls it "contradictory, fragmented, held together in a more or less haphazard whole" (Caste and Subaltern Consciousness, p. 170). Further exploring this contradictory consciousness, Chatterjee states:

Common sense (with or of subaltern) is the contradictory unity of two opposed elements: one, the autonomous element which expresses the common understanding of the members of the subaltern group engaged in the practical activity of transforming the world through their own labor, and other, the element, which is borrowed from the dominant classes and which expresses the fact of the ideological submission of the subaltern group. (p. 171)

The Artist's lover in the play keeps on filling her jar while waiting for the return of her lover. Her lover is punished for making the wood speak, shine and sing in forms but what can she do except being an audience of this tragedy. Her silence itself is an indication 
of the submissive mentality of the subaltern. Subalterns contain the world changing potentiality. Sometimes, they articulate or reveal this autonomous, world transforming consciousness whereas at other times, they remain subordinate to the ruling ideology. In this regard, the unity of these contradictory states of 'consciousness' constitutes their common sense.

The analysis above, made with special reference to Gramsci and Chatterjee establishes subaltern consciousness as something contradictory. Another question comes up: Does this contradiction get represented? What happens when either of the two elements (involved in the composition of subaltern consciousness) gets silenced? Necessarily, it silences the agency of the subalterns. But mostly, when subalterns get represented, they are either only shown to be violent, forceful and rebellion or they get projected as someone who subordinate to the will of ruling classes. In both cases, one does not get true representation. If this is the story of the subaltern, what about the gendered subaltern? The same principle holds true to her as well.

Subedi, in his attempt of representing the consciousness of gendered subaltern in this play, has explored the contradictory nature of subaltern consciousness. He presents both the elements involved in the composition of subaltern consciousness presenting the autonomous and borrowed consciousness of Maiju and other female characters in the play. Sometimes, the women articulate the autonomous consciousness whereas at other times, they remain subordinate to the ruling ideology. In this regard, the unity of these contradictory states of consciousness constitutes their common sense. The Artist's Lover's attempt of protecting her lover from a couple of strong men, displays her autonomous consciousness. In fact, a patriarchal society expects man to be 'protective' and woman to be 'helpless' but the Lover, by breaking the stereotypical images of patriarchy, appears as a rebellion. Her act of covering him again "by emulating a gesture of anger and confidence" (p. 62) and "protesting" with all her energy (p. 63) is an expression of her autonomous consciousness. But, she being the victim of the ideology of patriarchy, remains incapable in protecting her lover which produces her capitulation to the authority. A realization of her powerlessness and helplessness marks the end of her autonomous consciousness and the emergence of her sense of submission and subordination.

Her lover was punished for no fault and she could do nothing except being an audience of the tragedy that had fallen on herself and her lover drawing a permanent line 
of separation between them. Her submissive consciousness gets full-fledged expression in the questions she asks Maiju; “Maiju, what shall I do now!” (p. 64). Maiju’s response to her question, too displays the contradictory consciousness of subaltern:

We will seek the answer to this all

In the river

Across the river

In the cosmos of stones and wood

Tears are not failings

We will conquer with them one day. (p. 64)

Maiju's response comes as consolation to the Artist's Lover but within this consolation, there is also the expression of subaltern's mentality. Why does she propose to seek the answers in the future? Why not in present? Maiju, being familiar with the power of patriarchy, seems to have realized their powerlessness and helplessness but at the same time, she is moved by the appalling tragedy of the Artist's Lover which stimulates her sense of revolution. That is why, her response exhibits subaltern's mentality where the sense of revolution is mixed up with submission to authority. Having realized the dual nature of subaltern consciousness, Gautam Bhadra (1999) argues:

Defiance is not the only characteristics of the behavior of subaltern classes, submissiveness to authority in one context is as frequent as defiance in another. It is these two elements that together constitute the subaltern mentality. It is on the account of this combination that the poor and oppressed have, time and again and in different histories, made voluntary sacrifices in favor of the rich and the dominant, at least as often as they have rebelled against the latter. (p. 54)

Maiju's Contradictory consciousness is further explored and represented by Subedi through the Guard and the Poet. "She is getting married" (p. 70) but "she does not want to leave" (p. 69), informs the Guard in which the former (p. 70) stands for her submissiveness to authority, and the latter (p. 69) represents her autonomous consciousness. But patriarchy refuses to acknowledge her autonomous consciousness and individuality and forces her to 
borrow the ideology of dominant class which is evident in her acceptance of her marriage. Here, the playwright has exploited 'marriage' as a tool to represent the fragmented and episodic consciousness of Maiju. One can easily observe how her autonomous consciousness is being replaced by her submissiveness to authority. She is forced by patriarchy in spite of her no will and desire, to get married to a strange country "where she may have to sit/ Quietly listening to a tongue/ She's never heard before" (p. 70).

Maiju's contradictory consciousness further gets expression in the momentous questions in which she identifies herself with a river. The storm of protest is the expression of her autonomous mentality whereas, her silence accepting the situation, is borrowed from the dominant class and which expresses the fact of the ideological submission of Maiju. She tries to seek:

Where does it begin?

Where does it all end?

Who can tell me what I am

A river or a woman

A joy of time or a pain

That lurks behind wooden covers? (p. 71)

But Maiju couldn't dare ask these questions to the authority; she couldn't refuse the marriage imposed on her by patriarchy; she couldn't prove her agency and individuality. Why does she put forth these questions to the "blocks of woods, these stones and bricks" (p. 71)? Why does she remain silent infront ofthe authority? These questions hint towards her submissive mentality.

Patriarchy subalternizes women by refusing to hear her. As Bell Hook has argued that "Silence is often seen as [...] the right speech of womanhood" (p. 14), the women in the play, have been caged into silence by patriarchy which exploits their silence as the suitable device to nullify their existence. Subedi has shed light on this device of silence of patriarchy as nowhere in the play, women are seen speaking to the authority, i. e. patriarchy. To speak means to be unfeminine and the women characters adhere to their 
roles of womanhood. When the Artist is captured and taken away by a couple of strong men, the Artist's Lover makes no speech of protest but rather, chooses to be silent in front of the authority and same is the case with Maiju who is forcefully sent to an alien land. Maiju's forced exile in the name of marriage brings the storm of questions regarding her identity and existence. However, she is not even allowed to ask these questions. These questions are the expression of her remonstration against patriarchy but she is not allowed to express what she feels. Her speech is in fact, a soliloquy, as the Poet informs that she has shared with the 'block of woods', 'stones', 'bricks', 'river', and 'evening' (p. 71). Her speech in this context has become background music, as Bell Hook says, "audible but not acknowledged as the significant speech” (p. 15).

Dreams of Peach Blossoms fills up the silence that permeates history. Maiju's and the other women's stories of the past wrapped up in silence, are unknotted by Subedi displaying how the mainstreams culture denied their agency by silencing their voices. At the very outset of this play, the Poet's announcement of the 'dreams everywhere' reflects on the silent spots of history; sad and ailing stories of women lost in the grave of history. Subedi unfolds the painful experience of women of Bhaktapur that were silenced by patriarchy. However, they could not be silenced forever as they had the potentiality to express the truth, "Time here is silhouette" (p. 60), says the Poet and this time carries the elapsed, distorted and omitted stories of women and Subedi has relied on the memory of the Guard to blow the silence that covers the historiography, "Sun falls on our lines and bursts/That's why radiate" (p. 75) assert the young women which establishes their stories as palimpsest.

Spivak (1988), in her essay "Can the Subaltern Speak?", sees the case of representation beset with the problems. Her argument draws the conclusion that the subalterns cannot speak themselves, but, instead, they have got to be represented. However, the problem with representation is that the very investigator's voice overshadows the subaltern's voice. While evaluating the case of gendered subaltern, Spivak argues that whether it is West or East, the women are denied the position from which they can speak on their own as both spaces are patriarchies, in which women turned into the object of the male's desire, “There”, Spivak says, “is not space from which the sexed subaltern can speak" (p. 103). If so, how is the playwright Abhi Subedi able to represent the voice of gendered subaltern? Has his own subjective voice erased the voice of gendered subaltern? 
To begin with, Subedi's technique of unfolding the stories of gendered subaltern through a subaltern perspective, in this regard, is worthy to analyze. Spivak's declaration that "the subaltern cannot speak" (p. 104), has been interpreted as the lack of means and strategy on the part of subaltern to speak on their own. Subedi's attempt of unfolding the forgotten painful experiences of women through the character of the Guard, is an act of providing means and strategy on the part of the women to speak on their own. It is true that patriarchies, as Spivak (1996) argues, does not let women speak or does not acknowledge their voices even if speak, caging them into silence. But, Subedi, through the Guard, makes the audience hear the sound of water in a dry lake, rustle of leaves in a bare tree and into the feel of the times that are frozen in the artifacts and carved out stories. In that sense, Subedi has been able to explore the silent spots of history by representing the issue of gendered subaltern without erasing their voices.

Subedi explores the problem displaying the marginalization and subordination of women in history but without stating a solution to the problem. He does not go as far as to be didactic; thus, by not stating a solution to the problem, he seeks to invite varied responses from the readers. This open-ended structure of the play, too, strengthens Subedi's representation of gendered subaltern as an objective investigator. In his representation of women, he makes no claim to have full knowledge regarding the trauma, pain, tensions of women. Too breathtaking is their pain that the Poet, the mouthpiece of Subedi, decides to cast off his mantle and write poetry from a distance. However, Subedi has become successful in arousing the same tensions and pain in the heart of audience through which the women in the play undergo. A realization that the hitherto written history is the history of man written with the power of sword, itself is a critique of subordination and marginalization of women. In this sense, Subedi deconstructs the historiography through the representation of the gendered subaltern. How does Subedi represent the issue of gendered subaltern? How does he deconstruct the historiography? How far has he been successful to represent the mentality or consciousness of gendered subaltern? These are some of the prominent questions while assessing Subedi's representation of gendered subaltern.

Subedi, in his attempt of articulating the consciousness of gendered subaltern, is aimed at dismantling the hegemonic representation of women constructed by patriarchy. In a male dominated structure, the ideological construction of gender keeps the male 
dominant allowing the male to construct various stereotypes of women as a strategy to inflict domination and exploitation on them. The hegemonic representation of women serves the interest of patriarchy as it denies the subjectivity and voice of women. Dreams of Peach Blossoms travels back into the history by exposing the painful experiences of Bhrikuti and her cultural descendants- Maiju and the other women.

During its journey of the history, this play not only unfolds the bitter facts regarding women's stories, but also exposes the hegemonic representation of women and tries to dismantle it. The elite historiography has glorified the marriage of Bhrikuti with Tibetan King by sideling the tensions, pain and agonies of Bhrikuti. In fact, she has been set up as an ideal example of womanhood to be followed. Patriarchy has represented Bhrikuti as a title holder of patriotism and spiritual purity. This very positive-looking representation of Bhrikuti has, if truth be told, suppressed the very pain and tension that Bhrikuti underwent while heading for an alien country on the one hand, and on the other, this served as a strategy to conceal domination and exploitation patriarchy inflicts on women. As a matter of fact, Bhrikuti's marriage with the Tibetan King was a kind of barter system where Bhrikuti, as an object, was sold to the Tibetan King by the King of Bhaktapur to diminish the threat of attack from Tibet. In this business deal, both parties- the kings of Tibet and Bhaktapur- had benefits and Bhrikuti turned into an object. However, to omit this ruthless historical treatment, Bhrikuti was looked 'from below' as an ideal. Bhrikuti's hegemonic representation by patriarchy has made her, to use Spivak's term, Jashoda the Divine.

If Bhrikuti's hegemonic representation is the case of Jashoda the Divine, her cultural descendants-Maiju and the other women- come under the category of what Spivak calls, Jashoda the subaltern. Maiju and the other women in the play have been represented by patriarchy as objects to be handled by it. Patriarchy treats them as something with no individuality, agency and subjectivity. The Artist's Lover, a representative figure of all the other women, is unable to get her destination of love, and happens to face a terrible tragedy of severance with her lover because of patriarchy. Maiju is forced against her will to get married to an alien country, tradition, culture and language never to return home. The Artist's Lover cannot be one with her lover in spite of her will and desire and Maiju is forced for a marriage in spite of her no will and desire. In both cases, their subjectivity, agency and individuality have not been taken into consideration by patriarchy. The Artist's Lover and Maiju, both are represented as objects which patriarchy exploits to meet its 
interest. In this sense, Maiju and the other women in the play are looked 'from below' and they share the situation like that of, in Spivak's term, Jashoda the subaltern. As Spivak has pointed out, whether the woman is looked 'from above' merely as an object or 'from below' as a goddess, she is reduced into the object of the male's desire. The hegemonic male refuses to perceive women what they desire the latter to be. In this sense, there lies the parallelism between Bhrikuti the Divine and Maiju and the other women the subaltern. The icon of Bhrikuti the Divine, is used to dissimulate the exploitation inflicted on Maiju and the other the subaltern. As long as such hegemonic representation remains, the voice of women will perish under the great expectations created by that self-representation. Subedi's focus on the dark and silent spots of history exposes such hegemonic representation of women on the one hand, and on the other, dismantles and dismisses such representations by exposing the politics behind it.

To sum up, Subedi in his attempt of representing the consciousness of gendered subaltern in the play uses the subaltern perspective and marks a break in the existing historiography by bringing forth the issue of gendered subaltern who have been to the subject of the ruling class. Revisiting the history, he unfolds the distortions and omissions regarding women's reality and their invisibility in the historiography that is based on masculine norms, values and standards. Focused on Maiju culture, he brings forth the agonies and pain of women that are glossed over in the grand narrative. Subedi in his journey of the history, not only unfolds the painful experience of women erased from the pages of history but also exposes the hegemonic representation of women and tries to dismantle it. He is critical of patriarchy for glorifying Bhrikuti's marriage with the Tibetan King and for sideling the tension, pain and agonies of Bhrikuti. In his attempt of representing the consciousness of gendered subaltern, Subedi is successful as he represents both the opposed elements involved in the composition of subaltern consciousness. Mostly when subalterns get represented, they are either only shown to be violent, forceful or rebellion or they get projected as someone who subordinate to the will of the ruling classes. In both cases, one doesn't get true representation. But so far as Subedi is concerned, he focuses on both the opposed elements equally and his representation of common sense (with or of women) as the contradictory unity of two opposed elements justify the representation of the consciousness of gendered subaltern.

\section{References}

Full text of this article can be downloaded from www.craiaj.com and www.nepjol.info 
Basistha, P. (24 Dec. 2000). Dreams of peach blossoms. Deshantar Weekly.

Bhadra, G. (1999). Subalten studies: Writings on South Asian history and society, edited by Ranjit Guha, Vol. VI.

Bhandari, D. P. (29 Dec, 2000). Dreams of peach blossoms. The Kantipur Daily.

Chatterjee, P. Caste and subaltern consciousness. SS6, pp. 169-209, AU.

Davila, E. (2008). On being a good girl: Implication of Latinas in the United States. Women, images and realities: A multicultural anthology, Boston: McGraw-Hill.

Davis, C. (2003). Cultural memory in a Nepali play. Asian Theatre Journal, 20.2, pp 179-90.

Dhungana, B. (23 Dec. 2000). Dreams of peach blossoms in reality. The Kantipur Daily.

Glover, D., \& Kaplan, C. (2009). Femininity and feminism. New York: Palgrave.

Hooks, B. (1989). Talking back: Thinking feminist, thinking black. New York: South End Press.

Rayamajhi, S. (Nov. 2000- Jan. 2001). The forbidden dreams of peach blossoms. Across 4.3.

Spivak, G. C. (1996). A literary representation of the subaltern: Mahasweta Devi's Stanadayini. The Spivak reader: Selected works of Gayatri Chakravorti Spivak, London: Routledge.

Spivak, G. C. (1988). Can the subaltern speak? in Marxism and the interpretation of culture, edited by Cary Nelson and Lawrence Grossberg, Urbana IL: University of Illinois.

Spivak, G. C. (1997). Subaltern studies, vol. IV. New Delhi: Oxford University Press.

Subedi, A. (2001). Dreams of peach blossoms. Kathmandu: Across Publication. 